\title{
Exploration and Practice of the School-Enterprise Cooperation in Local Undergraduate Colleges and Universities to Cultivate Applied Talents
}

\author{
Wang $\mathrm{Li}^{\mathrm{a}}$, Shi Xiaoxing ${ }^{\mathrm{b}}$, Zhang Chunyang ${ }^{\mathrm{c}}$, Lv Ping ${ }^{\mathrm{d}}$ \\ College of Civil Engineering, Baicheng Normal University, Baicheng 137000,China

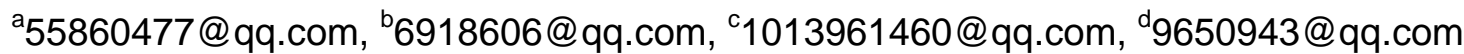

\begin{abstract}
Keywords: Local Undergraduate Colleges and Universities, School-enterprise Cooperation, Cultivate, Applied Talents, Practice Strategy
\end{abstract}

\begin{abstract}
Cultivating applied talents through the school-enterprise cooperation not only help improve the quality of teaching in local colleges and promote the students' occupation growth, but also can comprehensively improve the training mechanism of talents in the new century and take the optimization of the school-enterprise cooperation platform to meet the requirements of the development of employment market. This paper investigated the exploration and practice strategy of the training of applied talents by school-enterprise cooperation in local undergraduate colleges and universities, and put forward personal suggestions.
\end{abstract}

\section{Introduction}

At present, the higher education has shown a popular trend, the local undergraduate colleges and universities have three characteristics, namely, comprehensiveness, locality, teaching practice, and play a major role in the whole higher education system. However, compared with the key colleges and universities, the local universities have a short history of running, and the teaching strength is in urgent need of promotion, which has a great dependence on the local. Therefore, to promote the healthy development of the local undergraduate education, we must carry out the school-enterprise cooperation mode and strengthen the training of applied talents. This paper simply analyzed the importance of the implementation of school-enterprise cooperation mode, and from four aspects comprehensively investigated the practice strategy of cultivating applied talents of school-enterprise cooperation in local universities, namely, the construction of professional teaching training base; training mode of innovative talents, optimization of the local undergraduate college school-cooperation platform; the reform of the education training direction; strengthening of all teachers the training.

\section{The Important Significance of the Implementation of School-Enterprise Cooperation Mode}

Meet the Development Needs of Social Employment Market. For the civil engineering, it not only can further guide the students to understand the requirements of occupation technology in the future, but also can help schools to improve teaching strategies and update the teaching contents that using the school-enterprise cooperation mode to provide students with more practical learning platform. Most local colleges will adjust the educational policy according to the feedback of the enterprises, with the "market oriented" as the direction of teaching, pay more attention to cultivating students' innovative thinking and practical skills, so as to meet the development needs of the job market[1].

Promote Students' Occupation Growth. The traditional teaching mode of civil engineering focuses on theoretical knowledge, but the teaching of practice courses is lack of time, content and practice space, and that is bound to fragment professional personnel training and employment market demand, leading students to be lack of understanding for future occupation. Fully implementing the cooperation teaching mode not only reduces the gap between the practical work and the theory learning, but also can promote students to strengthen the operating skills, understand the workplace needs, constantly improve themselves and create diligent, hard-working spirit, understand the workplace needs, and constantly improve themselves, create diligent and 
hard-working spirit, and develop the workplace literacy during the internship[2].

Promote the Comprehensive Development of Local Colleges and Universities. From the perspective of the history of education development, the running time of local universities is not long, the overall quality of teachers has not yet reached the standard, and the discipline development is relatively slow[3]. For the civil engineering specially, the subject is a general designation of all kinds of engineering facilities in the construction of science and technology, the theoretical nature and practical nature are very strong, but in the actual teaching work, most local colleges only focus on theory teaching, the school's professional employment rate is low. Moreover, the civil engineering specialty is a discipline combining art and engineering between opening and closing, which has a unique cultural significance under the dual support of structural mechanics and humanistic spirit. After the use of school-enterprise cooperation mode to carry out the teaching of civil engineering, local colleges generally started the construction of practical training base, on one hand students can be autonomous to learn in school, on the other hand teachers can strengthen personal accomplishment in the school teaching work and optimize knowledge structure in the communication process with enterprise, enrich teaching experience and improve the ability of research and teaching of civil engineering major[4]. In addition, local colleges have the unique advantage in the natural environment, the geographical conditions, teaching resources and development space, and they service the local, so that can promote the dual development of local economy and the school, make the teaching of civil engineering become an important economic and cultural industry in the local, and for local train a large number of high-quality talents, to meet local the development of the demand for talents. Moreover, the school-enterprise cooperation mode known as "win-win mode" reputation, can realize complementary advantages of enterprise resources and human resources, enterprises need not worry about the staff qualifications and the level of theoretical knowledge, meanwhile local colleges do not have to worry about be unable to provide students professional practice platform, that can save the enormous cost of training talents and teaching, promoting win-win situation of enterprises and local colleges.

\section{Practical Strategies of Training Applied Talents by School-Enterprise Cooperation in Local Colleges and Universities}

The Construction of Professional Education Base. The traditional civil engineering major has the shortcomings that teaching resources relatively single, training space lack, the teacher-student ratio small, which seriously affected the teaching effect and causes the student satisfaction not high. Moreover, practical teaching of civil engineering can not give full play to start whenever and wherever because of being affected by site conditions, safety, time and other constraints. Therefore, in order to give full play to the educational value of the school enterprise cooperation model and achieve the goal of training applied talents, local universities should pay attention to the construction of professional education base and improve the construction of campus training base. In the process of constructing the practice base in schools, teachers should assist the colleges to strengthen cooperation and communication with construction enterprises, construction enterprises and supervision enterprise, listen to the staff of the enterprise, and build a cooperative education base with enterprises, put adequate funds for education training base, equip with teaching equipment and training tools. Note that the area of civil engineering practice training base can not be less than 1000 square meters, and the schools need build a modern civil engineering laboratory, Civil engineering survey training site, civil engineering training simulation site, civil engineering mechanics training site based on the practice base[5].

Secondly, local colleges should cooperate with the enterprises to jointly open up civil engineering training base outside quality, guide students to apply learn professional knowledge to practical work, and gradually realize the combination of professional theories and practice teaching, and constantly broaden students' career eye circles, increase their social experience, enrich their work experience and the ability of innovation. Moreover, the construction of civil engineering education base, must adhere to scientific outlook on development, pull the civil engineering 
professional education, practice skills training of civil engineering, research, production, professional services of civil engineering together, and use the scientific theory knowledge and the advantages of advanced technology to promote the comprehensive development of students in knowledge, skills and workplace literacy, training excellent high-tech talents for cooperative enterprises, improving the teaching effect of civil engineering.

On the other hand, civil engineering education is developing continuously with the progress of the times, the construction work of training base should adhere to the principle of survival of the fittest and dynamic principle, and get rid of unfavorable factors and obsolete, backward teaching equipment, creating good conditions for the use of school enterprise-cooperation mode[6].

Innovate the Talents Training Mode and Optimize the School-Enterprise Cooperation Platform in Colleges and Universities. According to the investigation and study, many local universities and colleges have low level of cooperation between schools and enterprises, which are restricted by teaching ability, cooperation platform, cooperation scope and intensity. Increasing the depth of cooperation, the local colleges must pay attention to the innovation of talent cultivation mode, constantly optimize the school-enterprise cooperation platform, integrate the civil engineering surveying, building ecology, construction economics, geotechnical mechanics and green building knowledge into the content of cooperation system, strive to explore new mode of cooperation, integrate the "win-win" goal, build "talents training system", "the talent exchange center" and "school-cooperation research center", which can just achieve resource sharing, technology sharing, talent sharing and common development goals.

Reform Education Direction of Talents Training. The reform direction of the talent training education must be based on modern target of civil engineering teaching, teachers should pay attention to improving the cooperative teaching method, case teaching method, micro-teaching method, action learning method and other learning process, guide students to enrich their knowledge in process of learning in school and practice in the enterprise and improve personal skills. The cooperative teaching method called "cooperative learning method", when using this method to carry out the teaching of civil engineering and practice, teachers need do a good guidance, divide learners into the cooperative learning group, and make them be clear of themselves' labor, to carry out cooperative learning activities for the students. Teachers play a very important role, has a great guide for students, of course as same as the teaching, and for students in the process of cooperative learning, teachers should guide students consciously, so that not only let students understand the teaching contents very well, but also stimulate the students' interest in learning. For teachers, the cooperative teaching method can shorten teaching time, reduce the pressure of teaching, but also in the process of cooperation and exchange of students, teachers can discover the problems in teaching, so that can master students' situation, according to the feedback constantly adjust the content and form of the civil engineering teaching, and develop a teaching plan for students to learn and accept, so that classroom effect will be more significant. Therefore, cooperative learning promotes the realization of the goal of teaching students in accordance with their aptitude, improves the quality of teaching, and has great practical significance [7].

The base-based teaching method is a kind of teaching mode based on the case, which different from the example teaching method and the traditional teaching method and has three basic benefits, namely, paying attention to the cultivation of students' independent thinking spirit, guiding the students to turn the knowledge into ability, and paying attention to the interaction and exchanges between the two sides. Micro-teaching creates a small and controllable teaching space, and teachers can decompose teaching work into individual teaching skills. Micro-teaching emphasizes the practical operation, and uses the demonstration, role play and video display and other ways to gradually train all kinds of individual teaching skills. Action learning takes "action" as the core and "completes the expected work" as the goal, and supports the learners to reflect themselves and exchange their learning experience with each other to form a "learning community". In addition, action learning emphasizes the creation of a good learning environment, advocates learners to understand the learning situation, summarizes the knowledge content of learning video, and improves the judgment ability and listening ability. 
In addition, teachers should pay more attention to the reform of the courses of civil engineering, optimize the curriculum structure, refine civil engineering construction design, civil engineering construction management, construction formwork design, steel scaffolding, mix design, building materials and construction process control performance of screening water and other course contents, and take the school-enterprise cooperation into the curriculum content, teaching system, organize students to full participate in civil engineering research projects, improve the level of students' theoretical knowledge and practical skills of civil engineering through practical teaching and research activities.

Strengthen the Training of Teaching Staff. Teachers have an important influence on the development of civil engineering education and effect of school-enterprise cooperation mode, to achieve the goal of cultivating applied talents, local universities must pay attention to solve the problem of teachers shortage and strengthen the training of all teachers. In the process of training teachers, local universities should pay attention to optimize the training content, innovate the training ways, guide teachers to realize the importance of co-operation, to establish the correct teaching attitude and training awareness, scientifically analyze the problems in teaching of civil engineering specialty, and conscientiously sum up the problem solving strategy. In the practice of teacher training management, the training assessment is composed of a series of tasks in order, including the determination of evaluation criteria, implementation of evaluation, comprehensive evaluation, evaluation of interviews and determination of improvement programs. Moreover, school can use the target assessment method and the 360 degree performance evaluation method to implement the assessment work of the training results. The target assessment method mainly take a certain stage of training teaching methods as the basis to make the evaluation results, which is a specific application of target management principle in the management of school-based teacher training, is associated with school-based training objectives of the management system. 360 degree performance evaluation method can make the school-based training evaluation result be more objective, comprehensive and reliable, which can promote the teachers comprehensively realize the development demands of themselves and civil engineering specialty teaching, improve teaching methods, motivate all teachers to participate in reform and optimize of training works, strengthen the construction of teachers team, and improve the overall morality cultivation.

\section{Conclusion}

In conclusion, it can strengthen the training work to meet the social demand for talents of high quality applied talents, promote the students' occupation growth, and improve the local colleges teaching force that carrying out school-enterprise cooperation mode in local colleges and universities. For improving school-enterprise cooperation in local universities and play the model role, both the universities and enterprises must pay attention to build the common teaching training base, strengthen cooperation and communication with construction enterprises, construction enterprises and supervision enterprise, put adequate funds for education training base, equip with teaching equipment and training tools; and innovative talents training mode, optimize the platform of school enterprise cooperation of local undergraduate colleges and universities, and integrate the "win-win" goal, build "talents training system", "the talent exchange center" and "school-cooperation research center"; and reform the direction of talents training education, update the teaching contents, improve students' theoretical knowledge level and civil engineering professional practice skills, but also should pay attention to strengthen the training of all teachers, build a high-quality teaching staff.

\section{References}

[1] Xue Chongmei. The status of enterprise accounting management and the methods of strengthening enterprise financial budget management [J]. Money China, 2015(29).

[2] Li Mingyu. Analysis and Countermeasures of bottleneck problems of college enterprise 
cooperation in Undergraduate Colleges[J].Shaanxi Education,2016(11).

[3] Xu Haizhi. Exploration and Reflection on the implementation of school enterprise cooperation and work study combination in Local Universities[J].Education and Vocation,2014(801).

[4] Lin Xue. Analysis and countermeasures of colleges "school enterprise cooperation" bottleneck problem [J].Education and Vocation,2016(01).

[5] Hua Xiaoyang, Wang Wenhao, Jiang Shengyong. Research on key issues of training engineering application talents by school enterprise cooperation[J].Research in Higher Education of Engineering,2013(01).

[6] Zhang Zhiming. Analysis and Countermeasures of bottleneck problems of college enterprise cooperation in Undergraduate Colleges[J].Shaanxi Education,2015(11).

[7] Chen Guocan, Xie Zhimin. The teachers' scientific research to improve the comprehensive quality of the Undergraduates[J].Fujian Building Materials,2011(09). 